\title{
Rennet Paste from Lambs Fed a Milk Substitute Supplemented with Lactobacillus acidophilus: Effects on Lipolysis in Ovine Cheese
}

\author{
A. Santillo, ${ }^{*}$ M. Quinto, $†$ M. Dentico, $†$ A. Muscio, ${ }^{*}$ A. Sevi, ${ }^{*}$ and M. Albenzio*1 \\ *Department of Production Sciences, Engineering and Economics for Agricultural Systems (PrIME), and \\ †Department of Agro-Environmental Science, Chemistry and Plant Protection (Di.S.A.C.D.), University of Foggia, Italy
}

\begin{abstract}
The present work was undertaken to evaluate the effects of Lactobacillus acidophilus supplementation of a milk substitute on the features of lamb rennet paste used for cheese making. Lipolysis in cheese manufactured with rennet paste from lambs receiving supplemented milk was also evaluated. Lambs were subjected to 3 different feeding regimens (mother suckling, MS; artificial rearing, AR; and artificial rearing with $7 \log _{10}$ $\mathrm{cfu} / \mathrm{mL}$ of Lb. acidophilus supplementation of the milk substitute, ARLb) and slaughtered at 20 and $40 \mathrm{~d}$ of age for each feeding treatment. Abomasa of the lambs were processed to rennet paste. Microbial loads, enzymatic activities (chymosin, pepsin, and lipases), and renneting characteristics of the lamb rennet paste were determined. Free fatty acids and conjugated linoleic acids were detected in cheese at $60 \mathrm{~d}$ of ripening. Addition of $7 \log _{10} \mathrm{cfu} / \mathrm{mL}$ of Lb. acidophilus to the milk substitute was carried out successfully. Total recovery of viable cells was recorded in milk supplied daily to the lambs in the ARLb group. The ARLb rennet had greater amounts of lactobacilli than did the MS or AR rennet, irrespective of the slaughter age of the lambs, and the ARLb rennet had higher concentrations of lactococci when lambs were slaughtered at $40 \mathrm{~d}$ of age. Chymosin and lipase activities were also higher in ARLb rennet than in MS or AR rennet from lambs slaughtered at an older age. Milk supplementation of ARLb lambs resulted in improved coagulating ability of the rennet and enhanced cheese lipolysis after $60 \mathrm{~d}$ of ripening. A reduction of all free fatty acids was observed in all cheeses when passing from 20 to $40 \mathrm{~d}$ of slaughter of the lambs. Conjugated linoleic acids were more abundant in ARLb cheeses at both 20 and $40 \mathrm{~d}$. Therefore, supplementation of the milk substitute with $L b$. acidophilus improved the enzymatic features of rennet and the healthful and nutritional characteristics of
\end{abstract}

Received February 9, 2007.

Accepted March 27, 2007.

${ }^{1}$ Corresponding author: m.albenzio@unifg.it the ovine cheese. Moreover, the addition of lactobacilli to the milk substitute made it possible to increase the slaughter age of lambs without detrimental effects on rennet characteristics.

Key words: lamb rennet paste, probiotic supplementation, lipolysis in cheese, conjugated linoleic acid

\section{INTRODUCTION}

Rennet pastes are artisanal products used almost exclusively in the manufacture of cheeses from ovine and caprine milk. There is a renewed interest in promoting the use of lamb rennet paste as an alternative to calf rennet to maintain the authenticity of traditional cheeses as well as to give different flavors to new products (Addis et al., 2005; Santillo et al., 2007).

Rennet composition varies along with several factors, such as source (animal species, pasture composition, microbial, and genetic features), physical state (liquid, powder, and paste), and enzymatic composition (chymosin:pepsin ratio, lipolytic enzymes).

The enzymatic content of rennet pastes is very heterogeneous and includes proteolytic, lipolytic, and milkclotting enzymes. Chymosin and pepsin represent the major components of enzymatic coagulant secretions extracted from the abomasa of ruminants (Sousa et al., 2001). Rennet paste contains lipases identified as pregastric esterases (PGE, of oral origin) and gastric lipase. It has been reported (Piredda and Addis, 1998; Addis et al., 2005) that variation in the lipase activities of rennet paste could be also attributed to slaughtering conditions (i.e., the fasting period before slaughter) and to the balance of different lipases (i.e., PGE and gastric lipase that behave differently), along with slaughter age.

Lipolysis is limited in most cheese varieties; exceptions are some Italian varieties, such as Pecorino and Provolone, which are manufactured with rennet paste containing PGE. Although lactic acid bacteria (LAB) are weakly lipolytic, they possess esterases or lipases, which release a low level of fatty acids during a long ripening period. Esterases or lipases from a number 
of strains of Lactococcus and Lactobacillus have been isolated and characterized (Fox, 2003).

Conjugated linoleic acids (CLA) are positional and geometric isomers of linoleic acid with conjugated double bonds; they have been shown to have potential health or nutritional benefits, primarily anticarcinogenic activity (Ha and Lindsay, 1990). Food products from ruminants, and dairy products in particular, are the major dietary source of CLA for humans (Alonso et al., 2003).

To our knowledge, no research has been conducted on the effects of adding probiotics to milk substitutes on the enzymatic composition of lamb rennet pastes used for cheese making.

The present study was undertaken to assess effects of the lamb feeding regimen (maternal milk, milk substitute, or a milk substitute supplemented with Lactobacillus acidophilus) and of lamb age at slaughter (20 and $40 \mathrm{~d}$ of age) on microbiological, coagulating, and enzymatic features of rennet paste, and on its lipolytic activity in ovine cheese. Finally, FFA and CLA contents were evaluated in the cheese samples analyzed at 60 $d$ of ripening.

\section{MATERIALS AND METHODS}

\section{Animal Management and Lamb Rennet Paste Production}

Twenty-four Comisana lambs were used in the study. Animals were divided into 6 groups of 4 according to a $3 \times 2$ factorial design, with lambs being subjected to 3 different feeding regimens (mother suckling, MS; artificial rearing, AR; and artificial rearing with $L b$. acidophilus supplementation, ARLb) and slaughtered at 20 and $40 \mathrm{~d}$. Lambs were grouped separately in strawbedded pens. Lambs in the MS group were kept with their dams throughout the trial, whereas lambs in the $\mathrm{AR}$ and ARLb groups were removed from their dams 24 to $30 \mathrm{~h}$ after birth and fed from buckets on a commercial milk substitute. The weight of the lambs at the beginning of the trial was $4.06 \pm 0.14 \mathrm{~kg}$ (mean \pm SEM) on average. A lyophilized culture of $L b$. acidophilus (DSM 20079; DSMZ, Braunschweig, Germany) was propagated in De Man, Rogosa, Sharpe broth (MRS Lactobacillus broth; Merck, Darmstadt, Germany) under anaerobiosis at $37^{\circ} \mathrm{C}$ for $24 \mathrm{~h}$. Cells were then cultured again under the same conditions, harvested by centrifugation, washed twice with sterile distilled water, and resuspended daily in milk substitute at a concentration of $7 \log _{10} \mathrm{cfu} / \mathrm{mL}$. The milk supplemented with $L b$. acidophilus was incubated at $37^{\circ} \mathrm{C}$ for $1 \mathrm{~h}$ and then given to the ARLb lambs.

Samples of milk destined for the ARLb lambs were plated anaerobically on MRS agar 3 times a week; mi- crobial counts were performed to test the survival of LAB added to the milk. Lambs were slaughtered at 20 and $40 \mathrm{~d}$ for extraction of abomasa. The abomasa were processed according to the local shepherds' protocol: The perivisceral fat was removed and the abomasa were filled with milk (50 to $100 \mathrm{~mL}$ ) and sodium chloride (50 to $100 \mathrm{~g}$ ). Stomachs were air-dried at 18 to $20^{\circ} \mathrm{C}$ and $70 \%$ relative humidity for $60 \pm 5 \mathrm{~d}$. The whole stomach was ground to obtain a paste, which was kept at $4^{\circ} \mathrm{C}$ in covered glass jars.

\section{Analyses on Lamb Rennet Paste}

Microbiology. Five grams of rennet paste was diluted in $45 \mathrm{~mL}$ of $0.9 \%$ (wt/vol) sterile saline solution and homogenized in a Stomacher Lab-Blender 400 (PBI International, Milan, Italy) for $1 \mathrm{~min}$. The aforementioned solution was also used to realize serial dilutions of samples that were plated on specific media for viable counts. The following media and conditions were used for analyses: plate count agar incubated for $48 \mathrm{~h}$ at $32^{\circ} \mathrm{C}$ for mesophilic bacteria; violet red bile agar incubated for $24 \mathrm{~h}$ at 37 and $44^{\circ} \mathrm{C}$ for total and fecal coliforms, respectively; violet red bile agar supplemented with 4-methylumbelliferyl- $\beta$-D-glucuronide and incubated for $24 \mathrm{~h}$ at $44^{\circ} \mathrm{C}$ for Escherichia coli; SlanetzBartley agar incubated for $48 \mathrm{~h}$ at $37^{\circ} \mathrm{C}$ for enterococci; M17 agar incubated, under anaerobiosis, for $48 \mathrm{~h}$ at $37^{\circ} \mathrm{C}$ for mesophilic lactococci; and MRS agar incubated under anaerobiosis for $48 \mathrm{~h}$ at $37^{\circ} \mathrm{C}$ for mesophilic lactobacilli.

Milk-Clotting Activity and Coagulum Characteristics. Determination of total milk-clotting activity was carried out according to the IDF (2006, standard 199). The total milk-clotting activity of the test sample was calculated by interpolation relative to a bovine rennet with an enzyme composition of 75:25 (chymosin:pepsin) and a known milk-clotting activity. Results are reported as international milk-clotting units (IMCU) per gram of rennet paste.

Coagulum characteristics were analyzed using a Foss Electric Formagraph (Foss Electric, Hillerød, Denmark); milk substrate was an aqueous solution of powdered low-heat sterile milk (Chr. Hansen, Milan, Italy) prepared with a calcium chloride solution of $0.5 \mathrm{~g} / \mathrm{L}$ and equilibrated at $30^{\circ} \mathrm{C}$ for $30 \mathrm{~min}$. A $200-\mu \mathrm{L}$ quantity of a $10 \%$ (wt/vol) aqueous rennet paste solution was used to coagulate $10 \mathrm{~mL}$ of milk substrate, and clotting time $(\mathrm{r})$, rate of clot formation $\left(\mathrm{k}_{20}\right)$, and clot firmness after $30 \min \left(\mathrm{a}_{30}\right)$ were measured.

Chymosin and Pepsin Activities in the Rennet Pastes. Aqueous rennet extracts $(20 \%$, wt/vol) were dialyzed for $3 \mathrm{~h}$ against $0.02 \mathrm{M}$ piperazine buffer at $\mathrm{pH} 5.3$ through a dialysis tubing cellulose membrane 
(D9277, Sigma-Aldrich, Milano, Italy). Samples of the same rennet extract, both dialyzed and nondialyzed, were used to determine chymosin and pepsin activities according to the IDF (1997, standard 157a). Enzyme activity is reported as rennet units (RU); $1 \mathrm{RU}$ is defined as the amount of enzyme contained in $1 \mathrm{~mL}$ of an enzyme preparation, which clots $10 \mathrm{~mL}$ of a reconstituted skim milk in $100 \mathrm{~s}$ at $30^{\circ} \mathrm{C}$.

Lipolytic Activity of the Rennet Paste on a Natural Substrate (Sheep Milk Cream Substrate). The lipolytic activity of each rennet paste on sheep milk cream substrate was determined according to the method described by Addis et al. (2005). Briefly, the milk cream was obtained by centrifugation of fresh sheep milk, and then mixed with reconstituted skim milk to obtain a final concentration of $25 \%$ (wt/wt). A 2.5 -mL quantity of rennet extract $(20 \%$, wt/vol) was added to $25 \mathrm{~g}$ of sheep milk cream substrate and incubated at $37^{\circ} \mathrm{C}$ for $24 \mathrm{~h}$. The lipolytic activity of each rennet was determined by titration of FFA in the total volume of incubate with $0.1 \mathrm{M} \mathrm{NaOH}$ until a $\mathrm{pH}$ of 8.5 was reached. The rennet extract $(2.5 \mathrm{~mL})$ and the blank (25 $\mathrm{g}$ of the same substrate without rennet extract) were also titrated in the same way. The lipolytic activity of each assay was calculated by subtracting the $\mathrm{NaOH}$ added to the blank and to the rennet extract from the $\mathrm{NaOH}$ volume added to the incubate.

Lipolytic activity is reported as lipolytic units (LU); $1 \mathrm{LU}$ is defined as the amount of enzyme producing, on the sheep milk cream substrate after $24 \mathrm{~h}$ at $37^{\circ} \mathrm{C}$, an amount of FFA titrable with $1 \mu \mathrm{Eq}$ of $\mathrm{NaOH}$, until a $\mathrm{pH}$ of 8.5 was reached. Values are given as LU per gram of rennet paste.

\section{Analyses of Ovine Cheese}

Ovine Cheese Production. Pecorino Foggiano cheese was made according to the method of Santillo et al. (2007). The same amount (30 $\mathrm{mL}$ of an aqueous solution at $60 \%$, wt/vol) of experimental rennet paste was used for cheese making. Three cheeses were produced using each experimental rennet paste and analyzed after $60 \mathrm{~d}$ of ripening.

Determination of FFA in Cheese. Volatile FFA in cheese were extracted with diethyl ether:hexane, after grinding with sodium sulfate and addition of $2.5 \mathrm{M}$ sulfuric acid (Ha and Lindsay, 1990). Free fatty acids were isolated using an aminopropyl column as adsorbent; desorption of the FFA was carried out with $2 \%$ formic acid in diethyl ether (De Jong and Badings, 1990). The underivatized FFA were separated directly by capillary GLC (Varian 3800, Varian, Milan, Italy) using a capillary column (CP 8853, WCOT fused-silica, $60 \mathrm{~m}, 0.32 \mathrm{~mm}, 0.25 \mu \mathrm{m}$, Varian). Operating conditions were as follows: helium at a flow rate of $1.3 \mathrm{~mL} / \mathrm{min}$, a flame-ionization detector at $250^{\circ} \mathrm{C}$, a split-splitess injector at $250^{\circ} \mathrm{C}$ with a split ratio of $1: 10$, and an injection volume of $1 \mu \mathrm{L}$. The temperature program of the column was 5 min at $65^{\circ} \mathrm{C}$, increased at a rate of $4^{\circ} \mathrm{C} /$ min to a final temperature of $220^{\circ} \mathrm{C}$, and then held for $20 \mathrm{~min}$. The individual fatty acid peaks were identified by comparison of retention times with those of a known mixture of standard fatty acids (Sigma). Free fatty acids were expressed as the percentage of total FFA. Free fatty acids in cheese were grouped into 3 classes: shortchain FFA (SCFFA, 4:0 to 10:0), medium-chain FFA (MCFFA, 12:0 to 16:0), and long-chain FFA (18:0 to 18:3) according to Addis et al. (2005).

Determination of CLA in Cheese. Pure CLA isomers were purchased as fatty acid methyl esters from Matreya Inc. (Pleasant Gap, PA). Acetonitrile and nhexane were for HPLC use (JT Baker, Deventer, the Netherlands). Total lipids from cheeses were extracted using a published procedure (Mills, 1959). Briefly, $5 \mathrm{~g}$ of cheese, $0.5 \mathrm{~g}$ of potassium oxalate (Fluka Chemie, Buchs, Switzerland), and $25 \mathrm{~mL}$ of ethyl alcohol (JT Baker) were homogenized for $2 \mathrm{~min}$. The homogenized mixtures were poured into a $100-\mathrm{mL}$ centrifuge tube with $10 \mathrm{~mL}$ of diethyl ether and $10 \mathrm{~mL}$ of petroleum ether (JT Baker) and centrifuged at $469 \times g$ for $7 \mathrm{~min}$ at room temperature. The lower phase was reextracted 2 more times with $10 \mathrm{~mL}$ of diethyl ether and petroleum ether $(1: 1, \mathrm{vol} / \mathrm{vol})$. The combined organic phases were transferred to a $500-\mathrm{mL}$ separatory funnel, to which 100 $\mathrm{mL}$ of distilled water and $7.5 \mathrm{~mL}$ of saturated sodium chloride were added. The organic extract was washed 2 more times with $25 \mathrm{~mL}$ of distilled water. Any emulsion formed was broken up by the addition of saturated sodium chloride (2 to $5 \mathrm{~mL}$ ) and allowed to stand for $30 \mathrm{~min}$. The combined organic layer was dried over anhydrous $\mathrm{Na}_{2} \mathrm{SO}_{4}$ and the organic solvent was removed by a rotary evaporator at $38^{\circ} \mathrm{C}$; total lipids were determined gravimetrically. A portion of total lipids (50 mg) was methylated by $\mathrm{NaOCH}_{3}$ (Sigma-Aldrich Chemie, Steinheim, Germany) at $50^{\circ} \mathrm{C}$, extracted with $n$-hexane, dried over anhydrous $\mathrm{Na}_{2} \mathrm{SO}_{4}$, and analyzed directly by HPLC.

The HPLC instrument (Thermo Separation Products, Piscataway, $\mathrm{NJ}$ ) was equipped with a membrane degasser (LDC Analytical, Riviera Beach, FL), a 10- $\mu$ L injection loop, and a UV diode array detector (Thermo Separation Products); 3 analytical silver-impregnated columns were fitted in series (ChromSpher 5 Lipids, 4.6 $\mathrm{mm}$ i.d. $\times 250 \mathrm{~mm}$, stainless steel, Varian). The mobile phase was $0.5 \%$ anhydrous diethyl ether (JT Baker) and $0.1 \%$ acetonitrile (JT Baker) in $n$-hexane and operated isocratically; the solvent flow was $1.0 \mathrm{~mL} / \mathrm{min}$. The CLA isomers were measured at $234 \mathrm{~nm}$ (Sehat et al., 1998). 
Table 1. Effects of feeding regimen and slaughter age of lambs on some microbial characteristics of rennet paste

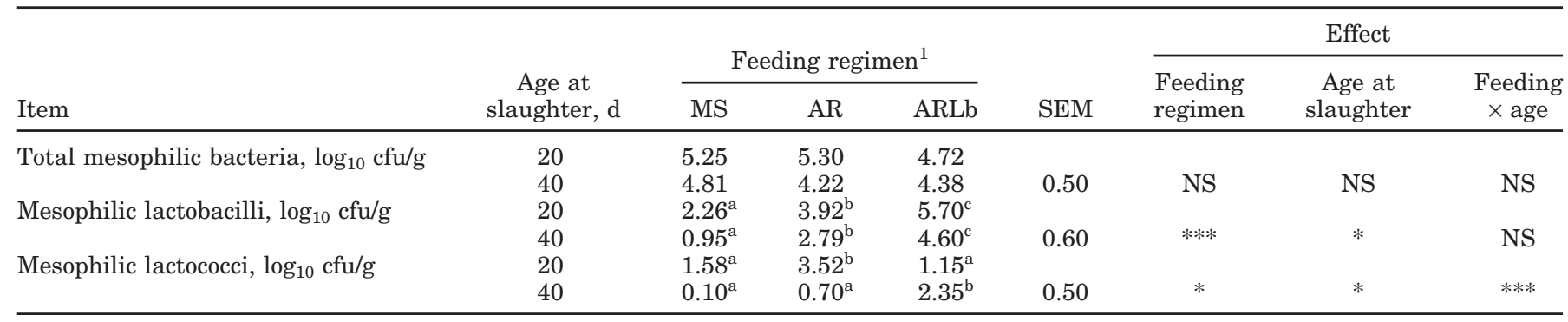

${ }^{\mathrm{a}-\mathrm{c}}$ Means with different superscripts differ for each item in rows and columns $(P<0.05)$.

${ }^{1} \mathrm{MS}=$ mother suckling; $\mathrm{AR}=$ artificial rearing; $\mathrm{ARLb}=$ artificial rearing with Lactobacillus acidophilus supplementation.

$* P<0.05 ; * * * P<0.001$.

\section{Statistical Analysis}

All the variables were tested for normal distribution using the Shapiro-Wilk test (Shapiro and Wilk, 1965). Data were processed by ANOVA using the GLM procedure of SAS (SAS Institute, 1999). The model used was

$$
\mathrm{y}_{\mathrm{ijkl}}=\mu+\alpha_{\mathrm{i}}+\beta_{\mathrm{ij}}+\gamma_{\mathrm{k}}+(\alpha \gamma)_{\mathrm{ik}}+\varepsilon_{\mathrm{ijk}}
$$

where $\mu$ is the overall mean; $\alpha$ is the effect of feeding regimen ( $\mathrm{i}=1$ to 3 ); $\beta$ is individual animal variation within the feeding regimen, $\gamma$ is the effect of age at slaughter ( $\mathrm{k}=1$ to 2 ); $\alpha \gamma$ is the interaction of feeding regimen $\times$ age at slaughter, and $\varepsilon$ is the error. $P<$ 0.05 was considered to indicate significant differences. Principal component analyses (PCA) were performed by SCAN for Windows (Minitab Inc., State College, PA) to obtain a visual representation of CLA isomer distribution in cheese samples.

\section{RESULTS AND DISCUSSION}

\section{Microbial Characteristics of Lamb Rennet Pastes}

Addition of $7 \log _{10} \mathrm{cfu} / \mathrm{mL}$ of $L b$. acidophilus to the milk substitute was carried out successfully; a total recovery of viable cells was recorded in milk given to lambs in the ARLb group. Diet and age at slaughter influenced the microbial characteristics of lamb rennet pastes (Table 1). At both 20 and $40 \mathrm{~d}$, rennet obtained from ARLb lambs showed the highest $(P<0.001)$ mesophilic lactobacilli cell load; AR lambs had an intermediate load, and MS lambs had the lowest values. At $20 \mathrm{~d}$ of age, AR lambs produced rennet with a higher $(P<$ 0.001) lactococci cell load than that of the ARLb and MS animals, whereas at $40 \mathrm{~d}$, the highest $(P<0.001)$ concentration of mesophilic lactococci was observed in the ARLb group. Skeie et al. (2001) found that lactobacilli had a positive influence on the growth of lactococci in milk, supplying minute amounts of peptides and AA that stimulated the growth of lactococci in milk. The lowest levels of mesophilic lactobacilli and lactococci in MS rennet paste were associated with free access of the ewe-reared lambs to the mother feeding zone so that MS lambs became accustomed to solid feed more rapidly than did artificially reared lambs. It is well known that young ruminants begin feeding on solid food beginning in the second week of life. In the early stages of ruminant life, the anaerobic acidophiles, coliforms, lactobacilli, lactose fermenters, and some anaerobes, predominate in the rumen, and with age and primarily with weaning, there is a slow transition to the microflora typical of the fully developed adult rumen (Agarwal et al., 2002).

Poor hygienic control is presumed to be one of the main problems with artisanal production of rennet pastes (Nunez et al., 1991). The rennet pastes analyzed in this study showed a satisfactory microbial quality, with the total mesophilic bacterial count being $<5 \log _{10}$ $\mathrm{cfu} / \mathrm{g}$ and no coliforms being detected (data not shown), in agreement with the acceptable threshold reported by Virto et al. (2003).

\section{Enzyme Composition of Lamb Rennet Pastes}

Chymosin, pepsin, and lipase activities are reported in Table 2. Chymosin and pepsin activities were affected by diet, age at slaughter, and their interaction $(P<0.001)$. In particular, chymosin activity was significantly higher in the AR and ARLb groups than in the MS group of lambs at $20 \mathrm{~d}$ of age, and was significantly higher in the ARLb group than in the other 2 groups at $40 \mathrm{~d}$ of age. Pepsin activity was 5- to 6-fold higher in the MS than in the AR and ARLb lambs slaughtered at $20 \mathrm{~d}$, but differences among groups disappeared in the rennet of lambs slaughtered at $40 \mathrm{~d}$ of age. Guilloteau et al. (1984) found that chymosin activity in lamb abomasa peaked at $2 \mathrm{~d}$ of age, then gradually decreased up to $7 \mathrm{~d}$, and had a second rise until $14 \mathrm{~d}$ before decreas- 
Table 2. Effects of feeding regimen and slaughter age of lambs on enzymatic acitivity in rennet paste

\begin{tabular}{|c|c|c|c|c|c|c|c|c|}
\hline \multirow[b]{3}{*}{ Item $^{1}$} & \multirow{3}{*}{$\begin{array}{c}\text { Age at } \\
\text { slaughter, d }\end{array}$} & \multirow{2}{*}{\multicolumn{3}{|c|}{ Feeding regimen $^{2}$}} & \multirow[b]{3}{*}{ SEM } & \multicolumn{3}{|c|}{ Effect } \\
\hline & & & & & & \multirow{2}{*}{$\begin{array}{l}\text { Feeding } \\
\text { regimen }\end{array}$} & \multirow{2}{*}{$\begin{array}{c}\text { Age at } \\
\text { slaughter }\end{array}$} & \multirow{2}{*}{$\begin{array}{c}\text { Feeding } \\
\times \text { age }\end{array}$} \\
\hline & & MS & $\mathrm{AR}$ & ARLb & & & & \\
\hline \multirow[t]{2}{*}{ Chymosin, RU/g } & 20 & $679.77^{\mathrm{b}}$ & $889.80^{\mathrm{d}}$ & $750.55^{\mathrm{d}}$ & & & & \\
\hline & 40 & $85.93^{\mathrm{a}}$ & $167.02^{\mathrm{a}}$ & $454.50^{\mathrm{c}}$ & 30.43 & $* * *$ & $* * *$ & $* * *$ \\
\hline \multirow{2}{*}{ Pepsin, RU/g } & 20 & $748.84^{\mathrm{a}}$ & 117.79 & 148.19 & & & & \\
\hline & 40 & 102.43 & 136.79 & 40.06 & 50.93 & $* * *$ & $* * *$ & $* * *$ \\
\hline \multirow{2}{*}{ Lipases, LU/g } & 20 & $210^{\mathrm{a}}$ & $2960^{\mathrm{b}}$ & $4400^{\mathrm{b}}$ & & & & \\
\hline & 40 & $475^{\mathrm{a}}$ & $990^{\mathrm{a}}$ & $3240^{\mathrm{b}}$ & 642 & $* * *$ & NS & $*$ \\
\hline
\end{tabular}

ing again. Hence, the decreased chymosin activity observed in all groups when passing from 20 to $40 \mathrm{~d}$ of slaughter age may be regarded as an age effect, probably due to both a decreased number of cells secreting prochymosin and the lambs starting with solid feed intake. Andrén and Bjorck (1986) reported that with continuous suckling, the secretion of prochymosin could last at least 6 mo. Casein in the milk is the main factor causing the secretion of prochymosin; thus, the abomasa of calves fed a CN diet contain a higher level of chymosin and a stable level of pepsin (Zhang et al., 2005). In rennet paste from ARLb lambs, the beneficial influence of supplementing the milk substitute with $L b$. acidophilus on cells secreting prochymosin may explain the highest levels of chymosin recorded in this group, compared with rennet paste from MS lambs, at both 20 and $40 \mathrm{~d}$ of age.

The lipase activities of rennet pastes on sheep milk cream substrate were influenced by the feeding regimen $(P<0.001)$ and the interaction of feeding regimen and age at slaughter $(P<0.05)$. In ARLb and MS rennet, lipase activities were not changed by the slaughter age of lambs, but in ARLb rennet, lipase activities were more than 20 times greater at $20 \mathrm{~d}$ of age and approximately 7 times higher at $40 \mathrm{~d}$ of age than in MS rennet. In contrast, $A R$ rennet showed higher lipase activities in abomasa from lambs slaughtered at $20 \mathrm{~d}$ than in those from older lambs. Different lipases, such as pregastric and gastric esterase, contribute to the lipolytic system in the rennet paste. Lipases have different specificities and activities (Pirisi et al., 2007) and are able to release FFA during cheese ripening. In calves, PGE activity is slightly affected by age and diet (Nelson et al., 1977). Collins et al. (2003) reported that suckling stimulates the secretion of PGE at the base of the tongue, which is carried into the abomasum with the milk. In this study, rennet obtained from lambs reared with their mothers always displayed the lowest lipase activity. This could be because MS lambs had access to the hay and concentrate given to their mothers, so solid feed intake led to a depression in PGE synthesis. Lipase activities did not significantly decrease with age except in the AR lambs. The high levels of lactococci found in ARLb rennet paste at $40 \mathrm{~d}$ could be responsible for the lipase activities remaining elevated in the abomasa of lambs supplemented with $L b$. acidophilus. Indeed, both $L b$. acidophilus and lactococci are able to release microbial lipases in the rennet paste. In particular, LAB possess esterolytic and lipolytic enzymes capable of hydrolyzing a range of esters of FFA and tri, di-, and monoacylglyceride substrates (Collins et al., 2003).

\section{Coagulating Performance of Lamb Rennet Pastes}

The clotting ability of rennet was evaluated in terms of IMCU (Table 3). The IMCU were affected by age at slaughter, with the highest values $(P<0.001)$ being recorded in rennet pastes obtained from the youngest animals, irrespective of the feeding regimen. An interaction effect of feeding regimen and slaughter age $(P<$ 0.05 ) was observed for this parameter, which could be explained by IMCU having a marked decrease with age in $\mathrm{MS}$ and $\mathrm{AR}$ rennet while remaining unchanged in $A R L b$ rennet. The IMCU values matched the enzymatic activity of experimental rennet paste in terms of chymosin and pepsin. The greater, although not significantly higher, values of IMCU recorded in the MS rennet from lambs slaughtered at $20 \mathrm{~d}$ was likely due to the contribution of pepsin to the coagulating activity of rennet.

Coagulating parameters of rennet paste are predictive of the performance of rennet in cheese making. In the present study, clotting time and clot firmness were affected by feeding regimen, slaughter age, and 
Table 3. Effects of feeding regimen and slaughter age of lambs on international milk-clotting units (IMCU) and on renneting parameters of rennet paste

\begin{tabular}{|c|c|c|c|c|c|c|c|c|}
\hline \multirow[b]{3}{*}{ Item $^{1}$} & \multirow{3}{*}{$\begin{array}{c}\text { Age at } \\
\text { slaughter, d }\end{array}$} & \multirow{2}{*}{\multicolumn{3}{|c|}{ Feeding regimen ${ }^{2}$}} & \multirow[b]{3}{*}{ SEM } & \multicolumn{3}{|c|}{ Effect } \\
\hline & & & & & & \multirow{2}{*}{$\begin{array}{l}\text { Feeding } \\
\text { regimen }\end{array}$} & \multirow{2}{*}{$\begin{array}{c}\text { Age at } \\
\text { slaughter }\end{array}$} & \multirow{2}{*}{$\begin{array}{c}\text { Feeding } \\
\times \text { age }\end{array}$} \\
\hline & & MS & $\mathrm{AR}$ & ARLb & & & & \\
\hline \multirow[t]{2}{*}{ IMCU, U/g } & 20 & $189^{\mathrm{c}}$ & $157^{\mathrm{bc}}$ & $148^{\mathrm{bc}}$ & & & & \\
\hline & 40 & $58^{\mathrm{a}}$ & $62^{\mathrm{a}}$ & $137^{\mathrm{b}}$ & 14.79 & $*$ & $* * *$ & $*$ \\
\hline \multirow[t]{2}{*}{$r, \min$} & 20 & $6.91^{\mathrm{a}}$ & $15.55^{\mathrm{b}}$ & $15.20^{\mathrm{b}}$ & & & & \\
\hline & 40 & $19.65^{b}$ & $27.80^{\mathrm{c}}$ & $18.31^{b}$ & 2.66 & $* * *$ & $* * *$ & $* * *$ \\
\hline \multirow[t]{2}{*}{$\mathrm{k}_{20}, \min$} & 20 & 1.25 & 1.27 & 1.31 & & & & \\
\hline & 40 & 1.4 & 3.31 & 1.42 & 0.71 & NS & NS & NS \\
\hline \multirow[t]{2}{*}{$\mathrm{a}_{30}, \mathrm{~mm}$} & 20 & $63.90^{c}$ & $61.80^{\mathrm{c}}$ & $59.46^{\mathrm{bc}}$ & & & & \\
\hline & 40 & $55.97^{\mathrm{b}}$ & $33.11^{\mathrm{a}}$ & $55.10^{\mathrm{b}}$ & 1.88 & $* * *$ & $* * *$ & $* * *$ \\
\hline
\end{tabular}

\footnotetext{
${ }^{\mathrm{a}-\mathrm{c}}$ Means with different superscripts for each item in rows and columns differ $(P<0.05)$.

${ }^{1}$ Renneting parameters: $\mathrm{r}=$ clotting time; $\mathrm{k}_{20}=$ rate of clot formation; $\mathrm{a}_{30}=$ clot firmness .

${ }^{2} \mathrm{MS}=$ mother suckling; $\mathrm{AR}=$ artificial rearing; $\mathrm{ARLb}=$ artificial rearing with Lactobacillus acidophilus supplementation.

$* P<0.05 ; * * * P<0.001$.
}

their interaction $(P<0.001)$, whereas rate of clot formation was unaffected by these categorical factors. In particular, clotting time did not change with age in the ARLb group, whereas in the other 2 groups an increase in this parameter was observed, being doubled in AR rennet and tripled in MS rennet when passing from 20 to $40 \mathrm{~d}$ of lamb age. As for IMCU and clotting time, clot firmness at 30 min was not affected by slaughter age in ARLb rennet but worsened in the other 2 groups. Hence, the data indicated that addition of lactobacilli to the milk replacer played a role in maintaining good coagulating performance in the rennet as the age of the lambs advanced.

\section{Lipolytic Pattern of Cheese}

To our knowledge, no research has previously been conducted on the effects of probiotic bacteria addition to rennet paste on the FFA patterns in cheese. Lipases in cheese originate not only from rennet preparation (rennet paste) but also from milk, adjunct starter, nonstarter bacteria, and exogenous lipases (Collins et al., 2003).

The profiles of individual FFA and of CLA $(9 c, 11 t$ 18:2 and $9 t, 11 t$-18:2) in cheeses manufactured with rennet pastes from lambs subjected to different feeding regimens and slaughtered at 20 and $40 \mathrm{~d}$ are shown in Table $4 \mathrm{~A}$ reduction of all FFA was observed in all cheeses as the lamb age at slaughter increased from 20 to $40 \mathrm{~d}$. The most abundant FFA were butyric acid (4:0), caproic acid (6:0), palmitic acid (16:0), oleic acid (18:1), and linoleic acid (18:2), along with previous results in ovine cheese (Albenzio et al., 2001). Addis et al. (2005) reported that when milk was the only feeding source for lambs, the rennet paste was enriched in PGE and able to preferentially release SCFFA. The ARLb cheeses displayed higher levels $(P<0.01)$ of SCFFA, MCFFA, and long-chain FFA than did the AR and MS cheeses at $20 \mathrm{~d}$, as an effect of the feeding regimen. It is worth noting that SCFFA and MCFFA remained higher, although not significantly, in ARLb when rennet from older lambs was used for cheese making.

In a previous report, Santillo et al. (2007) found that fresh curd cheese from ARLb lambs showed higher levels of lactobacilli and lactococci than did that from MS and AR lambs. Lipolytic enzymes associated with LAB are released into the cheese matrix through cell autolysis, thus contributing to lipolysis during cheese ripening. Because of their presence in the cheese at high numbers over an extended period, LAB are considered responsible for the liberation of significant levels of FFA (Collins et al., 2003).

An effect of diet $(P<0.001)$ was found for levels of $9 c, 11 t-18: 2$ and $9 t, 11 t-18: 2$, which were the most abundant CLA in cheeses. The highest values of both isomers were detected in ARLb cheese at 20 and $40 \mathrm{~d}$. Figure 1 shows the PCA biplot for the CLA composition of cheese samples as a function of the feeding regimen of lambs. The score plot shows how cheeses from the ARLb rennet paste lay in a well-defined zone, with CLA concentrations higher than those of the other cheese samples, as demonstrated by the loading plot of the variables. This result could be explained by considering that the CLA production capabilities of the $L b$. acidophilus (Alonso et al., 2003) added to the milk substitute used to feed the ARLb lambs could subsequently be transferred from the rennet paste to the cheese. Moreover, considering the health-promoting properties associated with CLA, it is noteworthy that the content of CLA found in the cheeses analyzed in this work was higher $(9 c, 11 t$ - 
Table 4. Free fatty acid and conjugated linoleic acid (CLA) contents in ovine cheese manufactured with rennet paste from lambs subjected to different feeding regimens and slaughtered at 20 and $40 \mathrm{~d}$ of age ${ }^{1}$

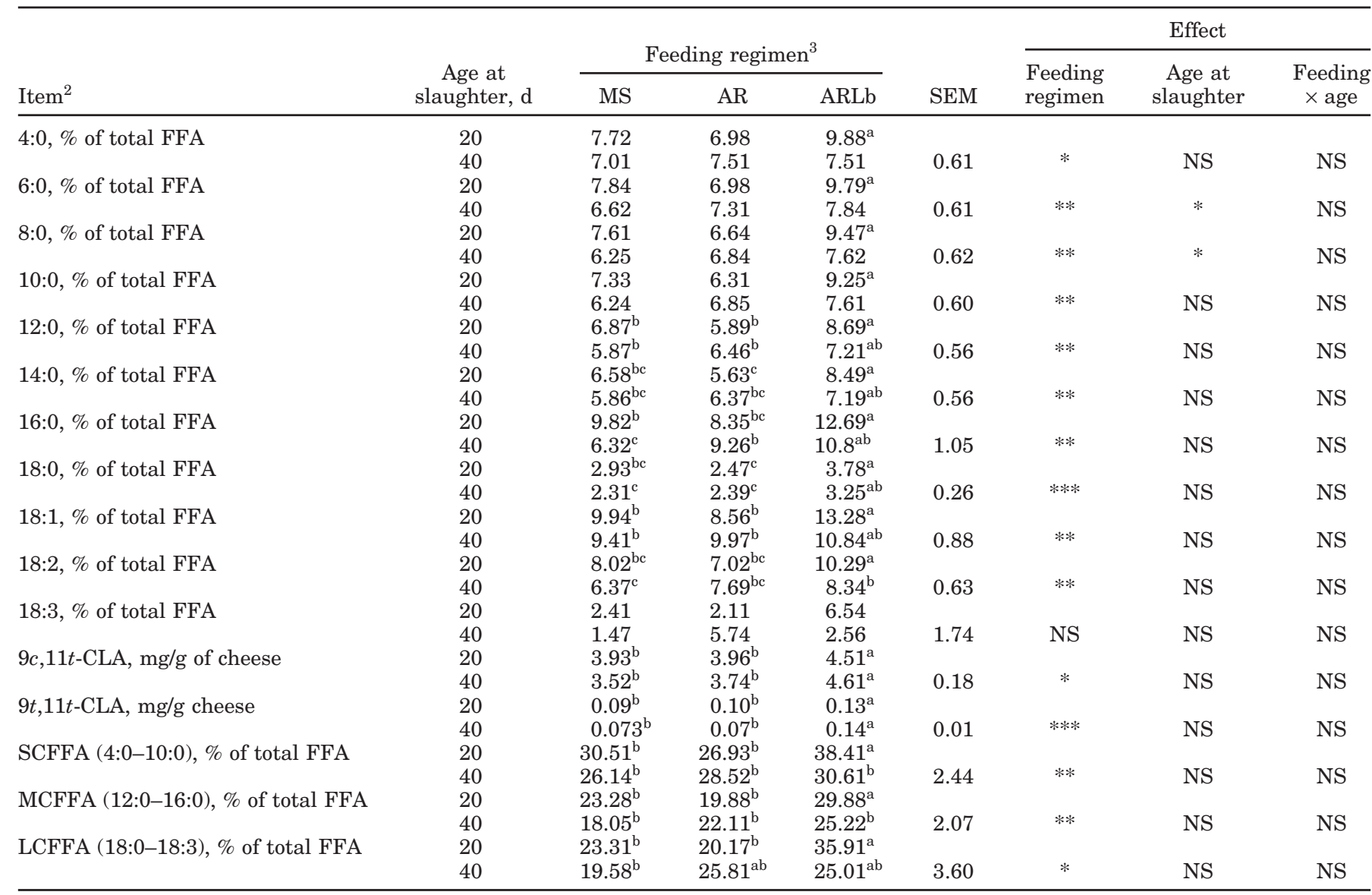

${ }^{\mathrm{a}-\mathrm{c}}$ Means with different superscripts for each item in rows and columns differ $(P<0.05)$.

${ }^{1}$ Values were recorded after $60 \mathrm{~d}$ of cheese ripening.

${ }^{2} \mathrm{SCFFA}=$ short-chain FFA; MCFFA = medium-chain FFA; LCFFA = long-chain FFA; $c=$ cis; $t$ = trans.

${ }^{3} \mathrm{MS}=$ mother suckling; $\mathrm{AR}=$ artificial rearing; $\mathrm{ARLb}=$ artificial rearing with Lactobacillus acidophilus supplementation.

$* P<0.05 ; * * P<0.01 ; * * * P<0.001$.

18:2, ranging between 3.0 and $5.4 \mathrm{mg} / \mathrm{g}$ of cheese) compared with the concentrations $(1.2$ and $2.5 \mathrm{mg} / \mathrm{g}$ of cheese) in other ovine cheeses reported by other authors (Zlatanos et al., 2002).

\section{CONCLUSIONS}

In a previous report, Santillo et al. (2007) demonstrated that addition of $L b$. acidophilus to the milk substitute sustained the viability and activity of lactic microflora in the rennet paste for cheese making. In the present study, supplementation of the milk substitute with lactobacilli resulted in higher activities of chymosin and lipases in the rennet compared with maternal milk and the nonsupplemented milk substitute, and maintained the enzymatic features of rennet un- changed with the increasing slaughter age of lambs, from 20 to $40 \mathrm{~d}$. The higher levels of lipolytic enzymes supplied by the ARLb rennet led to greater lipolysis in the cheeses. Furthermore, PCA analysis of the CLA isomers illustrated the higher content of CLA in cheese samples obtained using rennet paste from ARLb lambs, thus increasing their added value from a nutritional point of view. Therefore, supplementation of the milk substitute with $L b$. acidophilus improved enzymatic features of the rennet and made it possible to increase the slaughter age of lambs without detrimental effects on the rennet characteristics. This result can strongly encourage the use of rennet paste for cheese making, because it allows farmers to slaughter lambs when their carcass weight and characteristics are the most appreciated by the consumer. 


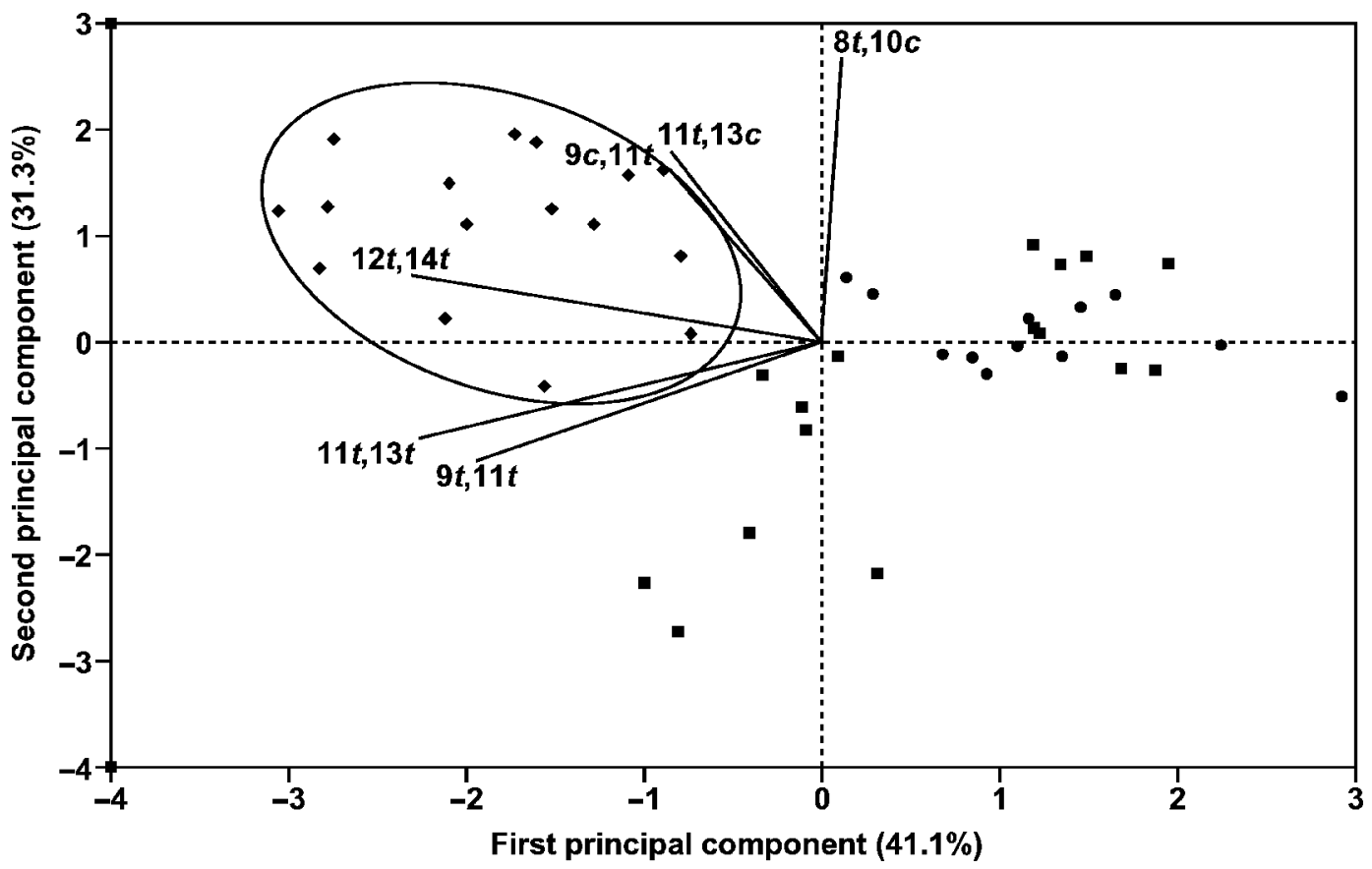

Figure 1. Principal component analysis of 6 conjugated linoleic acid isomers in the cheese samples analyzed. The first 2 principal components displayed $72.4 \%$ of the total variance. Cheese samples were obtained from lambs reared with the following feeding regimens: (Ш) artificial rearing; (-) mother suckling; and ( ) artificial rearing with Lactobacillus acidophilus supplementation.

\section{REFERENCES}

Addis, M., G. Piredda, M. Pes, R. Di Salvo, M. F. Scintu, and A. Pirisi. 2005. Effect of three different lamb rennets on lipolysis of the PDO Pecorino Romano cheese. Int. Dairy J. 15:563-569.

Agarwal, N., D. N. Kamra, L. C. Chaudhary, I. Agarwal, A. Sahoo, and N. N. Pathak. 2002. Microbial status and rumen enzyme profile of crossbred calves fed on different microbial feed additives. Lett. Appl. Microbiol. 34:329-336.

Albenzio, M., M. R. Corbo, S. U. Rehman, P. F. Fox, M. De Angelis, A. Corsetti, A. Sevi, and M. Gobbetti. 2001. Microbiological and biochemical characteristics of Canestrato Pugliese cheese made from raw milk, pasteurized milk, or by heating the curd in hot whey. Int. J. Food Microbiol. 67:35-48.

Alonso, L., E. P. Cuesta, and S. E. Gilliland. 2003. Production of free conjugated linoleic acid by Lactobacillus acidophilus and Lactobacillus casei of human intestinal origin. J. Dairy Sci. 86:1941-1946.

Andrén, A., and L. Bjorck. 1986. Milk-feeding maintains the prochymosin production in cells of bovine abomasal mucosa. Acta Physiol. Scand. 126:419-427.

Collins, Y. F., P. L. H. MacSweeney, and M. G. Wilkinson. 2003. Lipolysis and free fatty acid catabolism in cheese: A review of current knowledge. Intern. Dairy J. 13:841-866.

De Jong, C., and H. T. Badings. 1990. Determination of free fatty acids in milk and cheese. Procedures for extraction, clean up, and capillary gas chromatographic analysis. J. High Res. Chromatogr. 13:94-98.

Fox, P. F. 2003. Biochemistry of cheese ripening. Pages 320-326 in Encyclopedia of Dairy Sciences. Vol. 1. H. Roginski, J. W. Fuquay, and P. F. Fox, ed. MPG Books, Bodmin, Cornwall, UK.

Guilloteau, P., T. Corring, R. Toullec, and J. Robelin. 1984. Enzyme potentialities of the abomasum and pancreas of the calf: Effect of age in the preruminant. Reprod. Nutr. Dev. 24:315-325.
Ha, K. J., and R. C. Lindsay. 1990. Method for the quantitative analysis of volatile free and total branched-chain fatty acids in cheese and milk fat. J. Dairy Sci. 73:1988-1999.

IDF (International Dairy Federation). 1997. Milk and milk products. Ovine and caprine rennets. Determination of total milk-clotting activity. Standard No. 157a. FIL-IDF, Brussels, Belgium.

IDF (International Dairy Federation). 2006. Milk and milk products-Ovine and caprine rennets-Determination of total milkclotting activity. Standard No. 199. FIL-IDF, Brussels, Belgium.

Mills, P. A. 1959. Detection and semiquantitative estimation of chlorinated organic pesticide residues in foods by paper chromatography. J. Assoc. Off. Agric. Chem. 42:734-740.

Nelson, J. H., R. G. Jensen, and R. E. Pitas. 1977. Pregastric esterase and other oral lipase-A review. J. Dairy Sci. 60:327-362.

Nunez, M., B. F. Del Pozo, M. A. R. Marin, P. Gaya, and M. Medina 1991. Effect of vegetable and animal rennet on chemical, microbiological, rheological and sensory characteristics of La Serena cheese J. Dairy Res. 58:511-519.

Piredda, G., and M. Addis. 1998. Diet influence on enzymatic activities in lamb rennet paste. Sci. Tecnica Lattiero-casearia 49:129-138.

Pirisi, A., G. Pinna, M. Addis, G. Piredda, R. Mauriello, S. De Pascale, S. Caira, G. Mamone, P. Ferranti, F. Addeo, and L. Chianese. 2007. Relationship between the enzymatic composition of lamb rennet paste and proteolytic, lipolytic pattern and texture of PDO Fiore Sardo ovine cheese. Int. Dairy J. 17:143-156.

Santillo, A., M. Caroprese, R. Marino, A. Muscio, A. Sevi, and M. Albenzio. 2007. Influence of lamb rennet paste on chemical and enzymatic characteristics of Pecorino Foggiano cheese. Int. Dairy J. 17:535-546.

SAS Institute. 1999. SAS User's Guide: Statistics, Version 8.1 Edition. SAS Inst. Inc., Cary, NC.

Sehat, N., J. K. G. Kramer, M. M. Mossoba, M. P. Yurawecz, J. A G. Roach, K. Eulitz, K. M. Morehouse, and Y. Ku. 1998. Identification of conjugated linoleic acid isomers in cheese by gas chromatography, silver ion high performance liquid chromatography and 
mass spectral reconstructed ion profiles. Comparison of chromatographic elution sequences. Lipids 33:963-971.

Shapiro, S. S., and M. Wilk. 1965. An analysis of variance test for normality. Biometrica 52:591-601.

Skeie, S., C. Lindberg, and J. Narvhus. 2001. Development of amino acids and organic acids in Norvegia, influence of milk treatment and adjunct Lactobacillus. Int. Dairy J. 11:399-411.

Sousa, M. J., Y. Ardö, and P. H. L. MacSweeney. 2001. Advances in the study of proteolysis during cheese ripening. Int. Dairy J. $11: 327-345$.
Virto, M., F. Chávarri, M. A. Bustamante, L. J. R. Barron, M. Aramburu, M. S. Vicente, F. J. Pérez-Elortondo, M. Albisu, and M. de Renobales. 2003. Lamb rennet paste in ovine cheese manufacture. Lipolysis and flavour. Int. Dairy J. 13:391-399.

Zhang, F., J. Chen, F. Yang, and L. Li. 2005. Effects of age and suckling on chymosin and pepsin activities in abomasums of goat kids. Int. J. Dairy Technol. 58:115-118.

Zlatanos, S., K. Laskaridis, C. Feist, and A. Sagredos. 2002. CLA content and fatty acid composition of Greek Feta and hard cheeses. Food Chem. 78:471-477. 